\title{
The Effect Service Quality to Customer Satisfaction and Customer Loyalty of Argo Bromo Anggrek Train Jakarta-Surabaya in Indonesia
}

\author{
Sachro ${ }^{1}$, Sri Rahayu Pudjiastuti ${ }^{2}$ \\ 12 School of Economics Adhy Niaga Bekasi, West Java, Indonesia
}

\begin{abstract}
Abtrak: Customer Loyalty is important for cultivated by the company, therefore the aim of this study to prove how the effect of Service Quality and Customer Satisfaction in enhancing Customer Loyalty. Samples were service users Railway Transport Argo Bromo Anggrek Jakarta Surabaya by using purposive side. Sample size of 300 respondents. Data analysis using Structural Equation Model (SEM). The results showed that Services Quality significantly influence to customer satisfaction. Customer Satisfaction significant effect on Customer Loyalty. Service Quality is not yet significant effect on Customer Loyalty, so that Customer Satisfaction is a mediator of the relationship Service Quality on Customer Loyalty to PT Argo Bromo Anggrek Train JakartaSurabaya. The implications that Customer Satisfaction is capable of mediating the quality of care in improving Customer Loyalty.

Keywords: Service Quality, Customer Satisfaction and Customer Loyalty.
\end{abstract}

\section{Introduction}

Customer Loyalty has an important role in a company, because, retaining customers means maintaining the viability of the company. Reward of his own loyalty and long-term cumulative, so the longer a loyal customer of a product/service, the greater the profits derived by an enterprise of a prospect (Griffin, 2002).

The importance of loyalty to the survival of the company, then the company must continuously maintain and improve the loyalty of its customers. Therefore, to build Customer Loyalty, companies must have a good relationship with the customer so that the company can better understand the needs, desires and expectations of its customers. In putting the customer at the center of business activity vortex, expected the company always pay attention and give priority to customers in all the activities and programs carried out. So that the customer is a party that is always in precedence, the hope would feel satisfied, comfortable, and eventually became loyal to the company (Tjiptono, 2002).

Quality products and services play an important role in shaping customer satisfaction, but it is also closely related in creating profits for the company. The more quality products and services provided by the company is perceived by the customer satisfaction will be higher (Armstrong, 2002)

Bloemer et al, (1998) in his study showed a variable effect Service Quality on Customer Satisfaction and Loyalty. Cronin, Brady, and Hult (2000) describe the research results found that there was no direct effect between service quality on customer loyalty through customer satisfaction in the service of six companies studied. Service Quality has a close relationship with Customer Satisfaction. To determine the level of Customer Satisfaction needs to first know the Service Quality provided by the manufacturer to the customer. Customer Satisfaction will arise after a person experiences provided by the service provider (Parasuraman et al, 1994).

Some researchers regarding the Service Quality associated with Customer Satisfaction and Loyalty results are very diverse. There are states directly affect Service Quality on Customer Loyalty (Sunghyup Sean Hyun (2010) and Carrillat AF, et.al (2009), Ravichandran, (2010), Pollack (2009), Ziaul Hoq, (2009), there is also a states that do not affect Service Quality on Customer Loyalty (Bastos (2008). There is another which states that Customer Satisfaction is not a significant influence on Customer Loyalty (Sahadevs, and Keyoor P (2008).

At this time the field of transport is very tight competition. The passengers demand services quality Previous researchers who explore the Quality-Satisfaction-Loyalty (QSL) associated with the service industry such as Anderson and Fornell (2000) that stated there was a relationship between Service Quality, Customer Satisfaction and Loyalty. In the service industry, the core comes from the factors of Service Quality (Lin, 2007).

In addition, Customer Satisfaction and Loyalty always follow the Service Quality is one of the most frequently used variables to measure the success of marketing (Wen et al., 2005). Research goal is to analyze and explain how the impact of Service Quality on Customer Satisfaction and Customer Loyalty at PT Argo Bromo Anggrek Train Jakarta- Surabaya in Indonesia. 


\subsection{Customer Loyalty Concept}

\section{Literature Review}

Customer Loyalty has been widely researched and as a result the concept of loyalty has received many definition and interpretation in the literature. The concept of loyalty suffers from a lack of clear conceptual and operational definition. At a very general level, Customer Loyalty is the feeling of the attachment or affection for a company's people, products, or services (Jones and Sasser 1995)

Sudhahar et al. (2006) addressed the SERVLOYAL constructs into seven dimensions for scale construction process as behavioral dimension; attitudinal dimension; cognitive dimension; conative dimension; affective dimension; trust dimension; and commitment dimension. According to Walsh et al. (2008), three popular conceptualizations of loyalty exist as an attitude that leads to a relationship with the brand; as expressed in terms of revealed behavior; and as buying moderated by individual characteristics, circumstances, and/or the purchase situation.

\subsection{The Customer Satisfaction concept}

Kotler (2001) explains that satisfaction is a function of perceived performance and expectations. If the performance of the product or service is lower than expectations, consumers will be dissatisfied. If performance is as expected then the consumer will be satisfied, if the performance to exceed expectations, then the consumer will feel very satisfied. According to Zikmund, McLeod and Gilbert (2003) define satisfaction as a result of the evaluation after the purchase of the comparison between pre-purchase expectations with actual performance. Anderson and Srinivasan (2003) assessed Costumer Satisfaction categorized into five dimensions of overall satisfaction, customer favorite, customer loyalty, customer recommendation and priority option. Understanding Customer Satisfaction will facilitate companies to maintain Customer Satisfaction to products or services. As such, inferior products or services can be improved to allow customers with wonderful impression

\subsection{Service Quality Concept.}

Service Quality is crucial in retaining customers in a long time. Companies that have a superior service that will be able to maximize the company's financial performance (Gilbert et al, 2004). Services Quality can be the difference between success and failure in both service and manufacturing firms. Service quality, Customer Satisfaction have become the main concern of both manufacturing and service organization in the increasingly intensified competition for customers in today's customer-centered era (Wang et al., 2004). Services despite being a large and important segment of the world economies the concepts and practices of Service Quality are not as well developed as those of manufacturing quality (Douglas and Fredendall, 2004). The instrument that has become most prominent in Attempting to operationalize Service Quality is the gap models of service or SERVQUAL (Van der Wal et al., 2002; Wisniewski, 2001). Parasuraman et al. (1985) developed a conceptual framework for the SERVQUAL Model to measure consumer perceptions of service quality and later refined the models. Study refined the models and has five dimensions: tangibles, reliability, responsiveness, assurance, and empathy. Service Quality is critically determined by the disparity between the expectations and perceptions of the customer, and the service actually delivered (Curry and Sinclair, 2002; Ninichuck, 2001).

\subsection{The relationship Service Quality, Customer Satisfaction and Loyalty.}

The concept of Service Quality, Satisfaction and Loyalty are related to one another. Theoretically, the process can provide a reference in this study, which affect the quality of service loyalty both directly and indirectly affects loyalty through Customer Satisfaction. Service Quality can directly affect Customer Loyalty (Zeithaml, 1996) and affect Customer Loyalty indirectly through satisfaction (Caruana, 2002). Kotler (2003) explains that the relationship between satisfaction and loyalty is when customers reach the highest level of satisfaction that causes emotional bond and long-term commitment to the company's brand. Davis et al. (2008) suggest that the behavioral relationship between satisfaction and loyalty is not a linear one and has two threshold levels of crises.

\subsection{Research Design}

\section{Methods.}

This study uses a quantitative approach to data collection technique using two kinds of data, namely primary data and secondary data. Primary data is processed through the distribution of questionnaires. The questionnaire consisted of two parts, the first, is designed to obtain demographic data consisted of questions related to gender, age, marital status, and occupation of respondents. Second, questionnaires designed to measure Customer Loyalty and Satisfaction related to the Service Quality provided by PT Argo Bromo Anggrek train Jakarta to Surabaya and Surabaya to Jakarta. Questionnaires distributed to passengers at the Railway Train from Jakarta to Surabaya. 


\subsection{The Population and Sample.}

\subsubsection{Population.}

The population in this study was the passenger train Argo Bromo Anggrek Jakarta - Surabaya, but the population in this study cannot be quantified.

\subsubsection{Sample.}

Sampling was conducted using non-probability sampling, passengers who meet the criteria and the population has an equal chance to be selected as the sample (Malhotra, 2004). In accordance with the characteristics of the samples required sampling technique was purposive when researchers selected a sample based on some criteria (Cooper and Schindler, 2006). In this case the sample criteria used because researchers wanted to see loyalty, then the respondent should have done reuse.

\subsection{Data Analysis Techniques.}

Models performed in this study using Maximum Likelihood estimation (ML). This method is frequently used estimation methods for data analysis using Structural Equation Modeling (SEM) is considered more efficient and unbiased if the assumption of multivariate normality is met.

\subsection{RespondentsDescription}

\section{Results}

This chapter shows an overview of the respondent descriptions; among them are gender, age, the level of general education, rank and work experience. All of them are summarized and presented in the following table.

Table 4.1.

Respondent Description

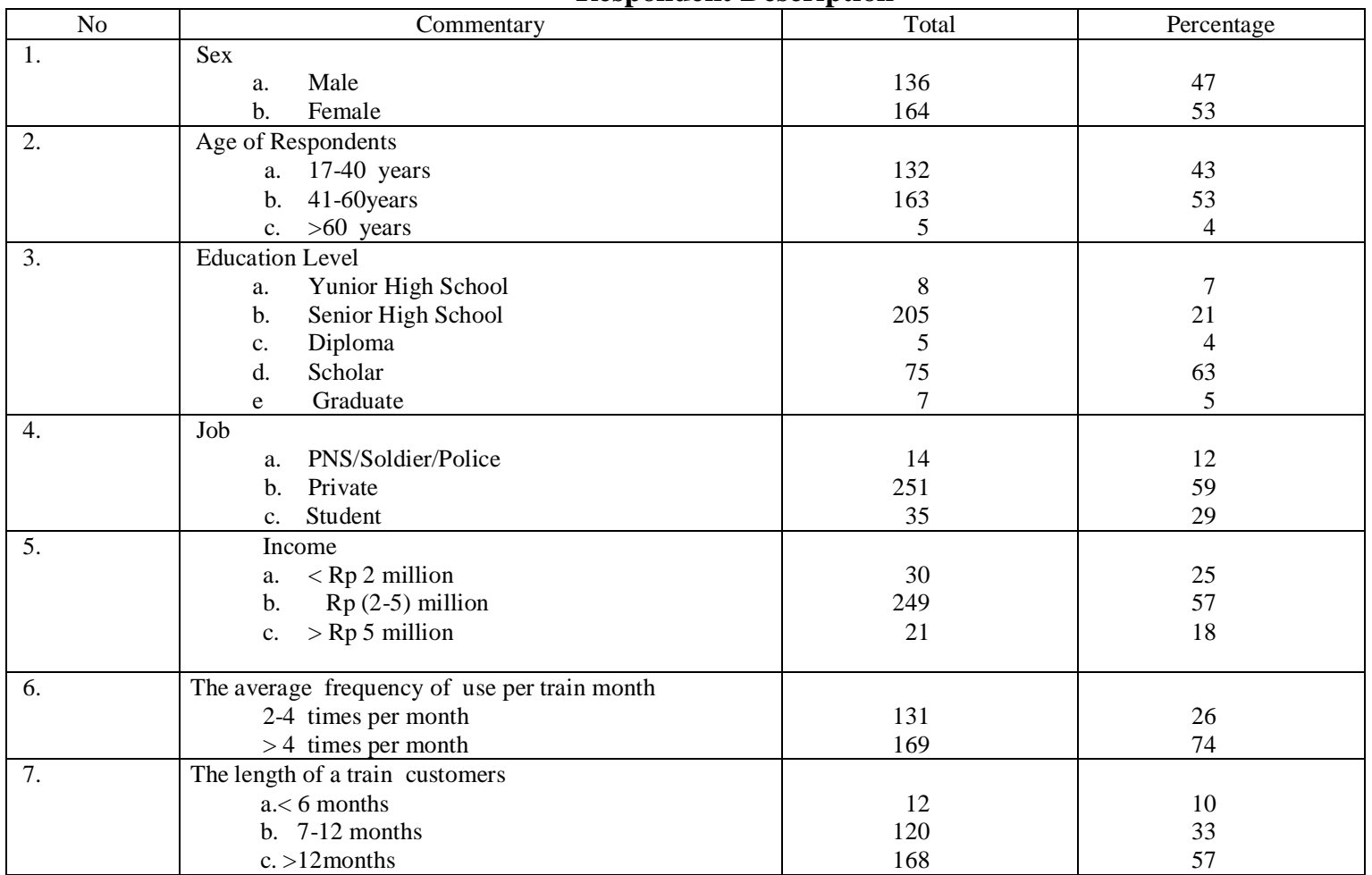

Sources: Research results 2011

Based on these results indicated some interesting findings about user profile rail transport service that most women passengers, these findings rein force the understanding when viewed from the aspect of group psychology that women tend to be more emotional, and almost 80 percent of women manage family finances and have a role in decision- making. In general, women usually have more characteristics highlight the nature of prudence, careful; always consider the efficiency, safety and security while driving. Naturally woman have her security concerns dominated by the productive age group with relatively high mobility character; was educated academics; work asprivate sector workers; constitute the middle class income levels two to five million 
dollars per month; when traveling a lot by train fire at least once a week, and more than a year to customers railway transportation services.

\subsection{DataAnalysisResults}

Inthis study was to test how far loyalty which is owned by the train passenger Argo Bromo Surabaya Jakarta when`subjects`are influenced by the service quality and customer satisfaction. Test results between constructs, is presented in Table 4.2 below:

Table 4.2

\section{Correlation among Constructs}

\begin{tabular}{|l|c|c|}
\hline \multicolumn{1}{|c|}{ Corelation } & Estimate & Information \\
\hline Servqual $\rightarrow$ Customer Satisfaction & 0,729 & Significant \\
\hline Customer Satisfaction $\rightarrow$ Customer Loyalty & 0,913 & Significant \\
\hline Servqual $\rightarrow$ Customer Loyalty. & 0,004 & Non Significant \\
\hline
\end{tabular}

Sources: Research results 2011

Table4.2. The high number of correlation $(>0.5)$ between the constructs showed apositive influence and direction. Thus, the greater the level of services quality provided, the more satisfied the customer using Argo Bromo Anggrek train. Strongest relationship found in the correlation between customer satisfaction on loyalty of 0.913 , but no significant service quality variable in influencing customer loyalty. The following describes a direct relationship between the variables:

Table 4.3 .

Direct Effect.

\begin{tabular}{|l|c|c|}
\hline \multicolumn{1}{|c|}{ Construct } & Service Qualities & Customer Satisfaction \\
\hline Customer Satisfaction & 0,729 & 0,910 \\
\hline Customer Loyalty & 0,004 & \\
\hline
\end{tabular}

Sources: Research results 2011

Based on the test results obtained by the variable service quality that has a direct positive effect on customer satisfaction variable was 0.729 with p-value 0.00 . The influence significant because p-value less than 0.05 . Thus, the first hypothesis is proven conclusively. Means that the higher the service quality it will be higher as well received by customer satisfaction. While the variable services quality either directly to the loyalty of 0.004 with p-value 0.971 . The resulting effect is not significant, so the hypothesis is rejected. As such, does not guarantee a service quality will be a loyal customer, because the service quality has a very weak influence on the ation of the loyalty of only $0.4 \%$. While the rest $(100 \%-0.4 \%=99.6 \%)$ is explained by other variables. The following models are presented in Figure 4.1

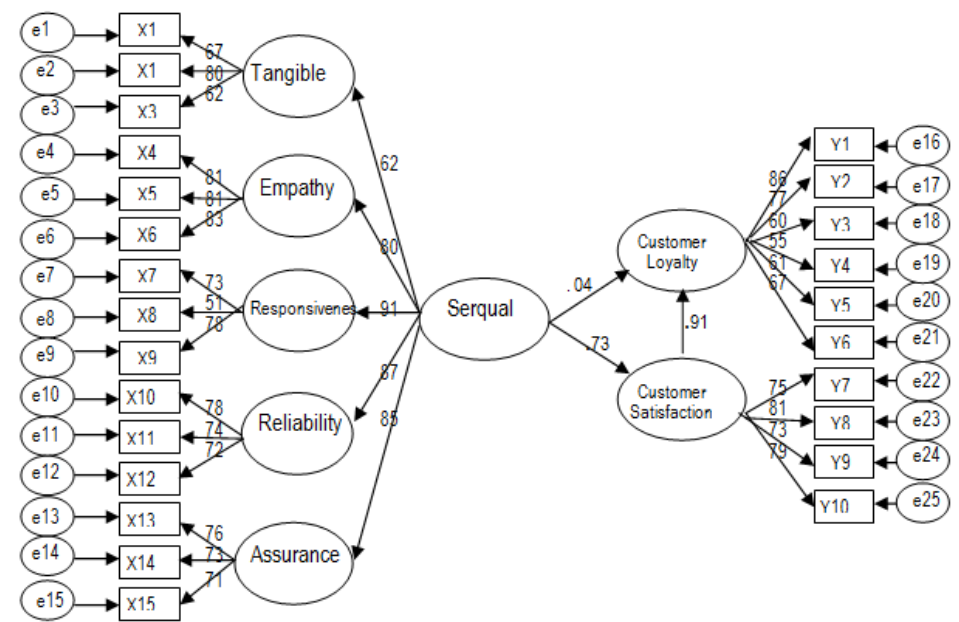

Figure 4.1ResearchModel 


\subsection{Discussion}

\section{Effect of kuallitas Service to customer satisfaction.}

Dimensions of service quality are formed through tangible, empathy, responsiveness, reliability and assurance have been able to improve Customer Satisfaction PT Argo Bromo Train Jakarta Surabaya. Hypothesis is constructed in this study was "the Service Quality significantly affect to Customer Satisfaction" it turns out, according to research hypothesis can be accepted. Service Quality is a powerful weapon in the company of excellence, especially service companies. Service Quality to trigger the company's success on all fronts. Service Quality is an obligation for companies, both manufacturing and service companies. Results of this study support previous research including Armstrong, (2002).

\section{Effect of Service Quality for Customer Loyalty.}

The hypothesis is built is "there is the effect of service quality on customer loyalty. The test results indicate that the variable is not significant Service Quality on Customer Loyalty so that the hypothesis is rejected. As such, does not guarantee a quality service will be a customer loyal, because the Service Quality has a very weak influence on the creation of loyalty. These results support the results of previous studies such as Bastos (2008); Caruana, (2002); Cronin, Brady, and Hult (2000) that there is no direct effect of Service Quality on Customer Loyalty and through Customer Satisfaction

\section{Influence of customer satisfaction on customer loyalty.}

Hypotheses that have been built that "There is the influence of Customer Satisfaction on Customer Loyalty. Based on the test results obtained by that variable customer satisfaction has a direct positive effect on customer loyalty variables so that the hypothesis can be accepted. Results of this study support the results of previous studies such as Kotler (2003) which states that Customer Satisfaction is a determinant in improving Customer Loyalty.

\section{Conclusion}

The results showed that the five dimensions of reliability, responsiveness, assurance, empathy, and tangibility shaper proven Service Quality. The results showed there is a strong and positive influence between the variables of Service Quality on Customer Satisfaction. This is evident from the results of the study showed that $72.9 \%$ of the variable Customer Satisfaction can be explained by the variable Service Quality, while the remaining $27.1 \%$ is influenced by other factors outside of the variable servicequality. This research note also that there is no effect between Service Quality on Customer Loyalty. While strong Customer Satisfaction and significant effect on Customer Loyalty. by $91 \%$ the remaining $9 \%$ is influenced by other variables. Customer Satisfaction Is a perfect mediator from the effect Service Quality on Customer Loyalty to PT Argo Bromo Anggrek Train Jakarta-Surabaya in Indonesia.

\section{Reference:}

[1] Griffin, J., (2002). Customer Loyalty: How to Earn It, How to Keep It, New and Revised Edition, Weekly publisher

[2] TjiptonoFandy (2002). Marketing strategy. Jogyakarta :Publisher Andi.

[3] Philip and Gary Armstrong, 2002, Principles of Marketing, Erlangga, Jakarta

[4] Bloemer, J., De Ruyter, K. \& Peeters, P. (1998). Investigating drivers of bank loyalty: the complex relationship between image, service quality and satisfaction. International Journal of Bank Marketing, 16 (7), 276-286.

[5] Cronin, J.J. Jr, Brady, M.K. and Hult, G.T.M.(2000), Assesing the effects of quality, value and customer satisfaction on consumer behavioral intentions in service environments, Journal of Retailing vol 76 No 2 pp 193-218

[6] Parasuraman , A., Zeithaml, V.A. and Berry, L.L, (1994), Moving forward in service quality research; measuring different customer expectation levels, comparing alternative scales, and examining the performance behavioral intentions link, Working Paper: Report number 94-114. Marketing Science Institute.

[7] Sunghyup Sean Hyun (2010). Predictorys of Relationship Quality and Loyalty in the Chain Restaurant Industry. Cornell Hospitaliry Quarterly. Ithaca: Vol.51, Edisi 2; pg.251

[8] Carrillat AF, Fernando, J., Jay, P.M.2009. Examining the impact of service quality; a meta analysis of empirical evidende. Journal of Marketing Theory and Practice. Armonk:. Vol 17, Edisi2; Pg.95, 16.

[9] Ravichandran, (2010), Influence of Service Quality on Banking Customers Behavioural Intentions. International Journal of Economics and Finance Vol 2 No. 4 November.

[10] Pollack B. (2009), Linking the Hierarchical Service Quality Model to Customer Satisfaction and Loyalty. Journal of Service Marketing, 23(1), 42-50

[11] Ziaul Hoq, Muslim amin (2009), The Role of Customer Satisfaction to Enhance Customer Loyalty, Eurasian Journal of Business and Economics 2009, 2 (4), 139-154.

[12] Bastos, J A.R., and Gallego, P.M (2008). Pharmacies Customer Satisfaction and Loyalty: A Framework Analysis. Journal of Marketing. Universidad de Salamanca

[13] Sahadev. Sunil, and Keyoor Purani. 2008. Modelling the Consequences of service Quality. Marketing Intelligence \& Planning26(6): 605-620. Emerald Group Publishing Limited.

[14] Anderson, E. W., \& Fornell, C. (2000). Faoundations of the American Customer Satisfaction Index. Total Quality Management, 11(7), 869-882. 
[15] Lin, W. B. (2007). An empirical of service quality model from the viewpoint of manament. Expert Systems with Applications, 32, $364-375$.

[16] Wen, C. H., Lan, L. W., \& Cheng, H. L.. (2005). Structural Equation Modeling to Determine Passengger Loyalty Toward Intercity Bus Services. Transportation Research Record, 1972, 249 - 255.

[17] Jones, T.O. and Sasser, E.W. (1995). "Why satisfied customers defect". Harvard Business Review, 73(6), 88-99

[18] Sudhahar, J. C., Israel D., Britto A.P., \& Selvam M. (2006). Service Loyalty Measurement Scale: A Reliability Assessment. American Journal of Applied Sciences, 3(4), 1814-1818.

[19] Walsh , G., Heiner. E., and Maren, W. 2008. Identification and analysis of moderator variables: Investigating the customer satisfaction-loyalty link, European Journal of Marketing, Vol.42 No.9/10, 2008, pp.977-1004.

[20] Kotler and Armstrong. 2001. Principles of marketing. Volume 1 issue 8 Erlangga.Jakarta:

[21] Zikmund, William G, Mcleod, Raymond, Gilbert, Faye W . (2003). Customer Relationship Management : Integrating Marketing Strategy and Information Technology . John Wiley and Sons.Inc, USA

[22] Anderson, R. E., and Srinivasan, S. c., 2003. E-Satisfaction and E-Loyalty: A Contingency Framework. Psychology and Marketing. 20 (2), 123-38.

[23] Gilbert, G.R. 2004. Measuring Customer Satisfaction in The Fast Food Industry: A cross-national Approach. The Journal of Services Marketing, 18.

[24] Wang, Y., Hing-Po, L. and Yang, Y. (2004), “An integrated framework for service quality, customer value and satisfaction: evidence from China's telecommunication industry”,'Information Systems Frontiersm, Vol. 6 No. 4, pp. 325-40

[25] Douglas, T.J. and Fredendall, L.D. (2004), "Evaluating the Deming management model of total quality in services",Decision Sciences, Vol. 35 No. 3, pp. 393-423

[26] Van der Wal, R.W.E., Pampallis, A. and Bond, C. (2002), "Service quality in a cellular telecommunications company: a South African experience", Managing Service Quality Vol. 12 No. 5, pp. 233-6

[27] Wisniewski, M. (2001), "Using SERVQUAL to assess customer satisfaction with public sector services",Managing Service Quality, Vol. 11 No. 6, pp. 380-91.

[28] Parasuraman, A., Zeithaml, V.A. and Berry, L.L. (1985), "A conceptual model of service quality and its implications for future research",Journal of Marketing, Vol. 49 No. 4, pp. 41-50

[29] Curry, A. and Sinclair, E. (2002), "Assessing the quality of physiotherapy services using SERVQUAL",International Journal of Health Care Quality Assurance, Vol. 15 Nos 4/5,pp. 197-205

[30] Ninichuck, B. (2001), "Service quality is the key to good business",Pest Control, Vol. 69 No. 9.

[31] Zeithaml, V.A., Berry, L.L., \& Parasuraman, A. 1996. The Behavioral Consequences of Service Quality. Journal of Marketing, 60.

[32] Caruana, A. 2002. Service Loyalty The Effects of Service Quality and The Mediating Role of Customer Satisfaction. European Journal of Marketing, 36

[33] Kotler, Phillip, 2003, Marketing Management, An Asian Perspective (Third Edition), Prentice Hall, Pearson Education Asia Pte. Ltd., Singapore.

[34] Davis -sramek, B. Mentzer, T.J. and Sank, P.T. (2008). "Creating Consumer durable retailer Customer loyalty through order fulfillment service operations"Journal of Operations Management 26(6), 781-797

[35] Malhotra, N.K. 2004. Marketing Research: An Applied Orientation. New Jersey: Pearson Education.

[36] Cooper, D.R., \& Schindler, P.S. 2006. Business Research Methods (9th ed.). New York: McGraw-Hill/Irwin. 